\title{
Severe paraneoplastic hypereosinophilia in metastatic renal cell carcinoma
}

\author{
Tilman Todenhöfer ${ }^{1}$, Stefan Wirths ${ }^{2}$, Claus Hann von Weyhern³ ${ }^{3}$, Stefan Heckl ${ }^{4}$, Marius Horger ${ }^{5}$, \\ Joerg Hennenlotter ${ }^{1}$, Arnulf Stenzl ${ }^{1}$, Lothar Kanz ${ }^{2}$ and Christian Schwentner ${ }^{1,6^{*}}$
}

\begin{abstract}
Background: Renal cell carcinoma can cause various paraneoplastic syndromes including metabolic and hematologic disturbances. Paraneoplastic hypereosinophilia has been reported in a variety of hematologic and solid tumors. We present the first case in the literature of severe paraneoplastic hypereosinophilia in a patient with renal cell carcinoma.

Case presentation: A 46 year-old patient patient with a history of significant weight loss, reduced general state of health and coughing underwent radical nephrectomy for metastasized renal cell carcinoma. Three weeks after surgery, the patient presented with excessive peripheral hypereosinophilia leading to profound neurological symptoms due to cerebral microinfarction. Systemic treatment with prednisolone, hydroxyurea, vincristine, cytarabine, temsirolimus and sunitinib led to reduction of peripheral eosinophils but could not prevent rapid disease progression of the patient. At time of severe leukocytosis, a considerable increase of cytokines associated with hypereosinophilia was measurable.
\end{abstract}

Conclusions: Paraneoplastic hypereosinophilia in patients with renal cell carcinoma might indicate poor prognosis and rapid disease progression. Myelosuppressive therapy is required in symptomatic patients.

Keywords: Paraneoplastic, Hypereosinophilia, Leukocytosis, Renal cell carcinoma, Leukemoid reaction, Encephalopathy

\section{Background}

Renal cell carcinoma can cause various paraneoplastic syndromes such as hypercalcemia, hypertension and ectopic hormone production [1]. Renal cell carcinoma can also provoke hematologic disturbances such as polycythemia due to an increased production of erythropoietin [2]. Hypereosinophilia has been reported as a paraneoplastic syndrome in several solid and hematological malignancies. We report the first case of severe paraneoplastic hypereosinophilia with cerebral infarction in a patient with metastatic renal cell carcinoma.

\section{Case Presentation}

Case presentation and management

A 46 year-old patient with no relevant diseases in past medical history had a history of significant weight loss,

\footnotetext{
* Correspondence: christian.schwentner@med.uni-tuebingen.de

'Department of Urology, University Hospital Tuebingen, Tuebingen, Germany Full list of author information is available at the end of the article
}

reduced general state of health and coughing. A whole body CT revealed a hypervascularized renal tumor with a level I tumor thrombus [3] (Figure 1) and multiple pulmonary lesions. At the time of primary diagnosis,

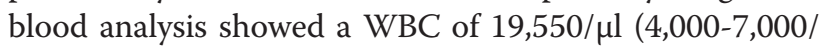
$\mu \mathrm{l})$ with $16 \%(0-6 \%)$ of eosinophilic granulocytes. The patient was admitted to our hospital 7 days after primary diagnosis (day 7) for radical nephrectomy, partial hepatectomy and reconstruction of the inferior vena cava. The intra- and postoperative course was uneventful. Histological examination showed clear cell renal cell carcinoma with sarcomatoid components (Tumor stage: pT4, pNx, M1, L0, V1, Rx, G3). According the MSKCC criteria, the patient was intermediate risk at time of diagnosis [4]. In an intersciplinary tumor board, the patient was recommended to begin with oral sunitinib. The patient was discharged from hospital 7 days after surgery (day 14) with a WBC of $14,360 / \mu l$. On day 29 the patient again presented at our hospital in a reduced
Ciomed Central 


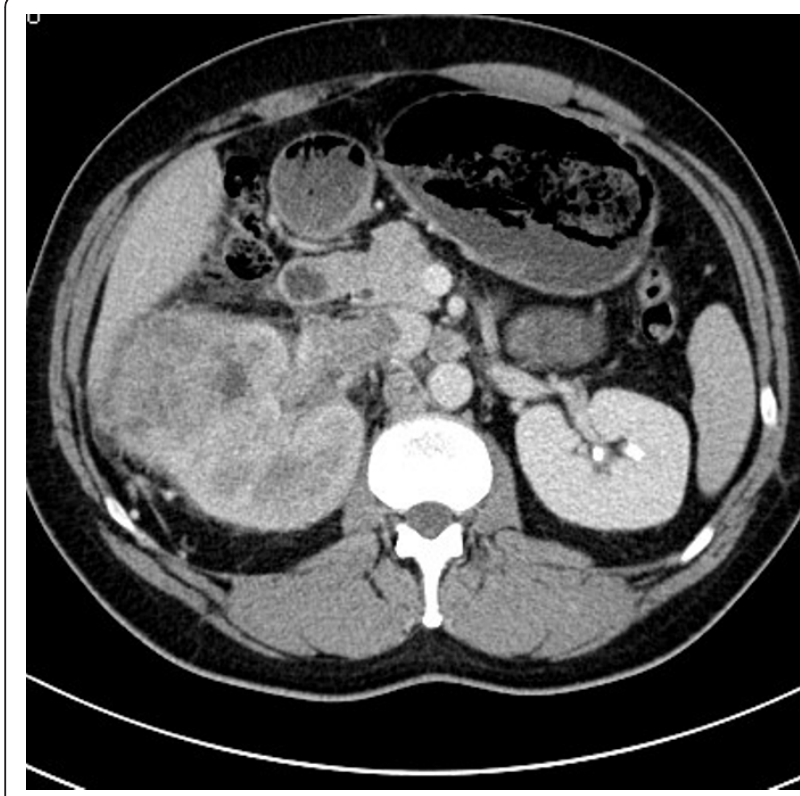

Figure 1 Preoperative imaging showing a hypervascularized renal tumor with a level I tumor thrombus in the vena cava.

general condition, with fever of $38.4^{\circ} \mathrm{C}$, tachycardia. Laboratory examination demonstrated leukocytosis of 37 $\times 10^{3} / \mu$ l with $34.2 \%$ of eosinophilic granulocytes. Ultrasound revealed a partially liquid mass with $10 \times 5 \mathrm{~cm}$ of size, which was suspicious of abscess formation, confirmed by computed tomography. The liquid mass was subsequently drained and $700 \mathrm{~mL}$ of serous fluid could be evacuated. Cultures of the fluid remained sterile. The patient was treated with intravenous antibiotics (vancomycine, tazobactam/piperacilline, and ciprofloxacin). However, leukocytes and eosinophilic granulocytes increased further despite antibiotic therapy and drainage.

On day 33, the patient presented with a weakness of the left arm. Multiple fresh embolic lesions were detected by MRI (magnetic resonance tomography) in the parietal, temporal and occipital lobes bilaterally (Figure 2). Furthermore a small infarction was detected in the cerebellum which led to the suspicion of cardiac emboli. Transthoracal echocardiography showed a profoundly decreased function of the left ventricle with inferior hypokinesia, a low-grade mitral valve insufficiency and no evidence of structures characteristic for endocarditis. The corresponding electrocardiogram showed a sinus tachycardia with ventricular extrasystoles (Lown classification 2). Ultrasound of extracranial vessels did not show significant stenosis. As at this point leukocytes had further increased up to $57,390 / \mu l$ with $37.7 \%$ of eosinophilic granulocytes (Figures 3 and 4).

Several tests were performed to rule out non-cancer causes of hypereosinophilia such as parasitic infections, allergy (including determination of serum mast cell tryptase), hypereosinophilic syndrome due to FIP1L1/ PDGFR receptor mutations and aberrant lymphocytes (no CD4-positive CD3-negative lymphocytes characteristic for lymphoproliferative hypereosinophilic syndrome), which remained all negative. Consequently, the patient was submitted to the department of medical oncology and received steroids and cytoreductive therapy with hydroxyurea. Doses of hydroxyurea and prednisone were increased stepwise up to $3 \mathrm{~g} /$ day and $100 \mathrm{mg} /$ day, respectively. Moreover, the patient received vincristine once $(2 \mathrm{mg})$ and 2 doses of cytarabine $(2 \times 150 \mathrm{mg} / 24$ h) as cytoreductive therapy of symptomatic hypereosinophilia (Figure 3).

A CT performed 2 weeks after the drainage of the fluid collection showed a massive progression of the retroperitoneal tumor mass in the surgical bed (Figure 5). Progress of the pleural and pulmonary metastases could be observed as well. Systemic therapy with temsirolimus (25 mg/once a week) was initiated, as at this point, swallowing difficulties (leading to parental nutrition) did not permit oral therapy with sunitinib. This led to a shortterm response of pulmonary and pleural manifestations (according to RECIST). The retroperitoneal tumor mass also responded to temsirolimus with tumor necrosis. However, a CT performed one month after initiation of temsirolimus therapy revealed a progressive disease of local relapse with hepatic, pancreatic and diaphragmatic invasion.

Administration of antiproliferative drugs for treatment of hypereosinophilia (cytarabine, hydroxyurea and vincristin) and renal cell carcinoma led to significant reduction of leukocytes and eosinophils as well as pancytopenia (Figure 3).

We performed a multiplex cytokine assay based on Luminex ${ }^{R}$ technology $\left(\right.$ Progen $^{R}$ ) to determine levels of multiple cytokines of serums drawn on day 44 (> 200.000 leukocytes/ $\mu \mathrm{l})$ and day $74(8,580$ leukocytes/ $\mu \mathrm{l})$. On day 44, we found severely increased concentrations of multiple cytokines and their receptors including bFGF, G-CSF, GM-CSF, HGF, IL2-RA, MCP-1 and MIP-1b. Results are shown in Table 1.

As swallowing difficulties disappeared, according to his will the patient was set on sunitinib $50 \mathrm{mg} / \mathrm{d}$ two months after nephrectomy. The patient could be discharged from hospital in reduced general condition 11 weeks after nephrectomy. Due to further disease progression, the patient died 4 months after primary diagnosis.

\section{Discussion}

Hypereosinophilia is most commonly associated with allergy and parasitic infections. Furthermore, several drugs, pulmonary and gastrointestinal diseases have 

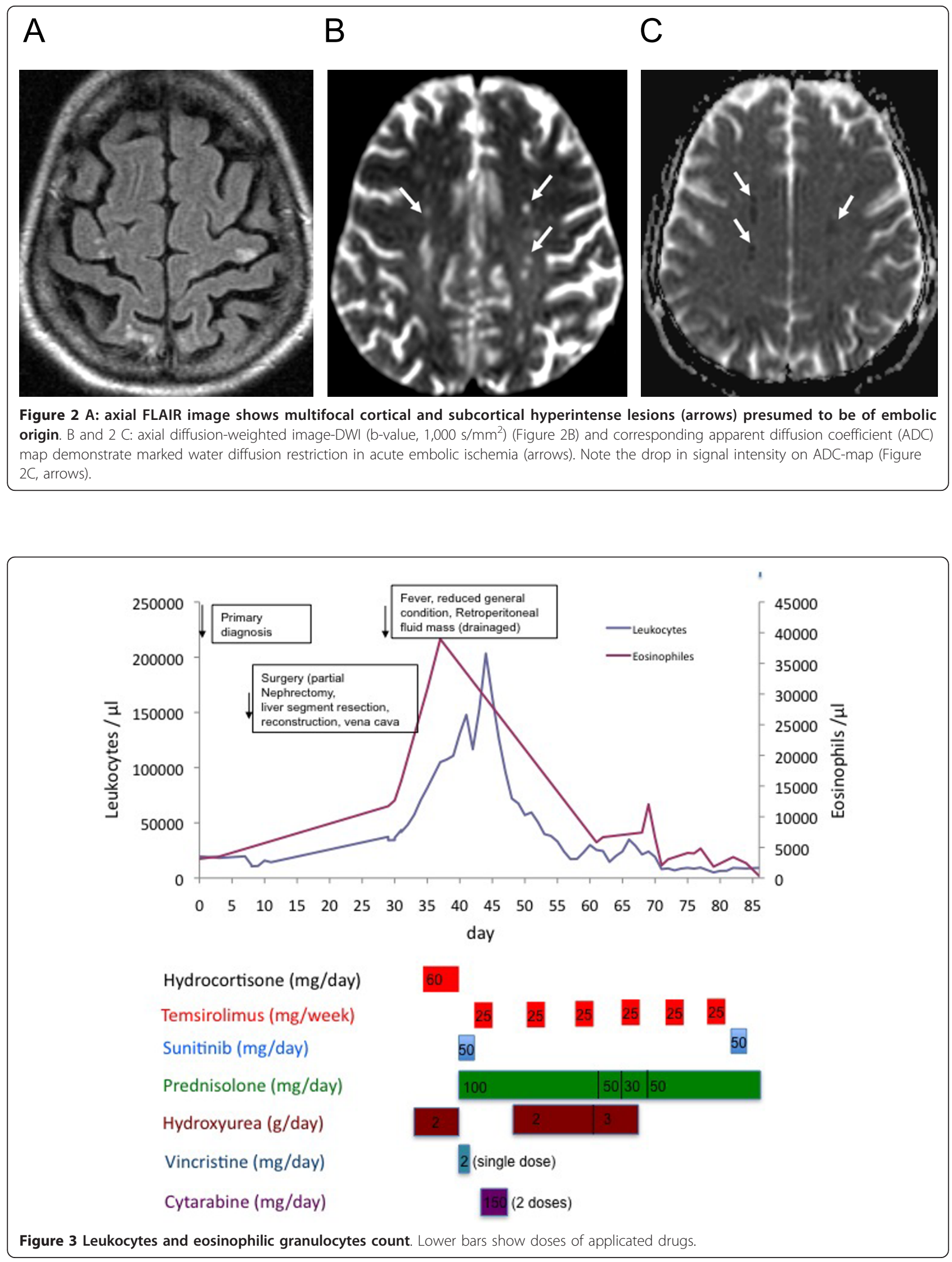


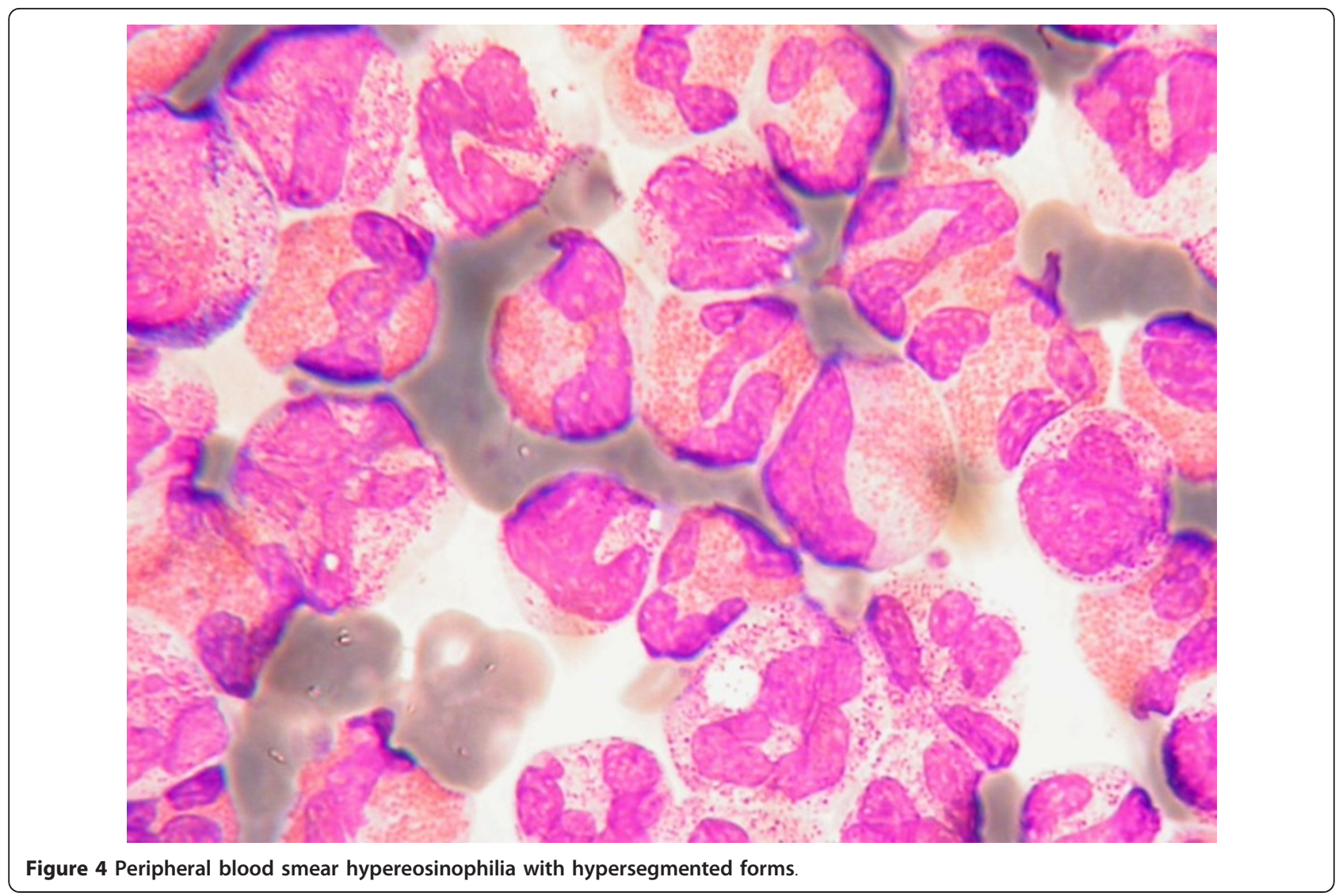

been identified as important causes for hypereosinophilia $[8,9]$. Within recent years, a couple of molecular alterations have been identified to account for malignant hypereosinophilic syndromes including rearrangements of the PDGFR receptor [8]. A mild to moderate increase ( $>500 / \mu \mathrm{l}$ to $<1,500 / \mu \mathrm{l}$ ) of eosinophils can be found in

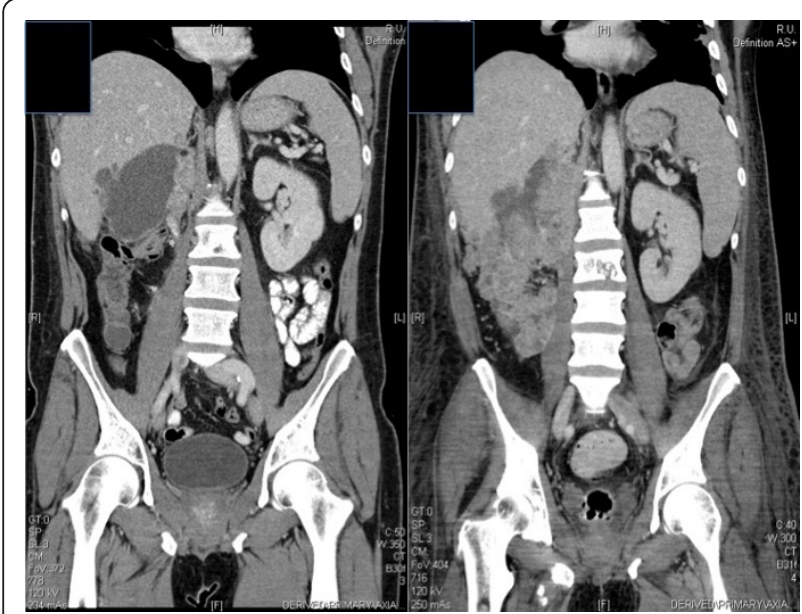

Figure 5 Progression of retroperitoneal tumor mass after radical nephrectomy within 4 weeks (coronal CT-images). up to $5 \%$ of patients with malignancies [10]. Severe peripheral hypereosinophilia $(>5,000 / \mu \mathrm{l})$ has been described in a variety of hematologic and solid tumors including gastrointestinal tumors [11,12], bronchial carcinoma [10], sarcomas [13] and prostate cancer [14]. Several cytokines produced by the primary tumor have been identified to account for increased production of eosinophilic granulocytes in the bone marrow including interleukin-3, interleukin-5 and GM-CSF (granulocytes macrophages stimulating factor) $[12,15,16]$. Other mechanisms for hypereosinophilia in patients with malignancy include an eosinophilotactic response due to necrosis in the tumor and increased production of eosinophils due to tumor cell dissemination in the bone marrow [9]. In the case presented here, we found increase of multiple cytokines at the time of massive leukocytosis and hypereosinophilia. G-CSF and GM-CSF which may be secreted by tumor cells and induce production of eosinophils $[17,18]$ were significantly elevated. Soluble receptor of interleukin 2 (IL2-RA) has been shown to be an important mediator of autocrine and paracrine regulation of eosinophils [19]. MIP-1a which is secreted by eosinophils and induces further leukocyte activation was also significantly elevated [20]. Both, elevation of interleukin 8 and MCP-1, may be 
Table 1 Levels of multiple cytokines at time of excessive leukocytosis (day 44) and after administration of cytoreductive drugs) (day 74) measured by ultiplex cytokine testing (Progen)

\begin{tabular}{|c|c|c|c|c|}
\hline Cytokine & Unit & Reference & Day 44 & Day 74 \\
\hline EGF & $\mathrm{pg} / \mathrm{ml}$ & -780 & 201 & 15,8 \\
\hline Eotaxin & $\mathrm{pg} / \mathrm{ml}$ & $175.8 \pm 49.3$ & 20,4 & 11,6 \\
\hline FGF-Basic & $\mathrm{pg} / \mathrm{ml}$ & $1,5-6,0$ & 40,8 & 23,5 \\
\hline G-CSF & $\mathrm{pg} / \mathrm{ml}$ & $27.34 \pm 8.00$ & 93,5 & $<$ LOW $>$ \\
\hline GM-CSF & $\mathrm{pg} / \mathrm{ml}$ & $-2,3$ & 40,6 & 19,8 \\
\hline HGF & $\mathrm{pg} / \mathrm{ml}$ & $120 \pm 120$ & $<\mathrm{HIGH}>$ & 4480 \\
\hline IFN-a & $\mathrm{pg} / \mathrm{ml}$ & $16.8 \pm 6.59$ & 25,3 & $<$ LOW $>$ \\
\hline IFNy & $\mathrm{pg} / \mathrm{ml}$ & & $<$ LOW $>$ & $<$ LOW $>$ \\
\hline IL-10 & $\mathrm{pg} / \mathrm{ml}$ & $9.2 \pm 1.5$ & 19,3 & 15,8 \\
\hline IL-12 p40/p70 & $\mathrm{pg} / \mathrm{ml}$ & $171.1 \pm 6,25$ & 104 & 52,6 \\
\hline IL-13 & $\mathrm{pg} / \mathrm{ml}$ & $25.5 \pm 2.94$ & 35,7 & $<$ LOW $>$ \\
\hline IL-15 & $\mathrm{pg} / \mathrm{ml}$ & $16.2 \pm 4.0$ & $<\mathrm{LOW}>$ & 45,2 \\
\hline IL-17 & $\mathrm{pg} / \mathrm{ml}$ & $0-127$ & 28,8 & 23,6 \\
\hline IL-1b & $\mathrm{pg} / \mathrm{ml}$ & $40.2 \pm 8.78$ & 25,7 & 12,5 \\
\hline IL-1RA & $\mathrm{pg} / \mathrm{ml}$ & $189 \pm 22$ & 979 & 241 \\
\hline IL-2 & $\mathrm{pg} / \mathrm{ml}$ & $2.4 \pm 0.8$ & 9,16 & 6,01 \\
\hline IL-2R & $\mathrm{pg} / \mathrm{ml}$ & $426.5 \pm 22.4$ & 12300 & 18300 \\
\hline IL-4 & $\mathrm{pg} / \mathrm{ml}$ & $3.34 \pm 0.84$ & 35,8 & $<$ LOW $>$ \\
\hline $\mathrm{IL}-5$ & $\mathrm{pg} / \mathrm{ml}$ & & $<\mathrm{LOW}>$ & $<$ LOW $>$ \\
\hline IL-6 & $\mathrm{pg} / \mathrm{ml}$ & $22.8 \pm 7$ & 330 & 299 \\
\hline IL-7 & $\mathrm{pg} / \mathrm{ml}$ & & 66,4 & 47 \\
\hline IL-8 & $\mathrm{pg} / \mathrm{ml}$ & $9.56 \pm 0.4$ & 652 & 111 \\
\hline IP-10 & $\mathrm{pg} / \mathrm{ml}$ & $4.5-27.1$ & 73,6 & 27,3 \\
\hline MCP-1 & $\mathrm{pg} / \mathrm{ml}$ & $173.2 \pm 15.04$ & 1110 & 377 \\
\hline MIG & $\mathrm{pg} / \mathrm{ml}$ & $22.1-52.4$ & $<$ LOW $>$ & $<$ LOW $>$ \\
\hline MIP-1a & $\mathrm{pg} / \mathrm{ml}$ & $88.1 \pm 14.31$ & 179 & 45,8 \\
\hline MIP-1b & $\mathrm{pg} / \mathrm{ml}$ & $135.1 \pm 29.22$ & 2640 & 278 \\
\hline RANTES & $\mathrm{pg} / \mathrm{ml}$ & $1100-4360$ & 3750 & 664 \\
\hline TNFa & $\mathrm{pg} / \mathrm{ml}$ & $34.32 \pm 11.46$ & 9,21 & 5,81 \\
\hline VEGF & $\mathrm{pg} / \mathrm{ml}$ & $76.6 \pm 6.07$ & 65,5 & 24,1 \\
\hline
\end{tabular}

Low $=$ concentration below detection limit, High = above detection limit. Reference values were obtained from [5-7]

explained by TNF-mediated activation of eosinophils [21]. All these cytokines were significantly lower at time of normal leukocyte count. However, it is not possible to define the exact mechanism of hypereosinophilia in this patient, as the source of the cytokines remained undefined and mediators causing hypereosinophilia may also be induced by eosinophils themselves. The tumor presented with extensive necrotic areas showing massive infiltration of eosinophils (Figure 6). Tumor necrosis has been discussed as a factor promoting tumor related hypereosinophila [22]. However, as a steady increase of leukocytes was observed after resection of the tumor with necrotic areas, tumor necrosis cannot be regarded

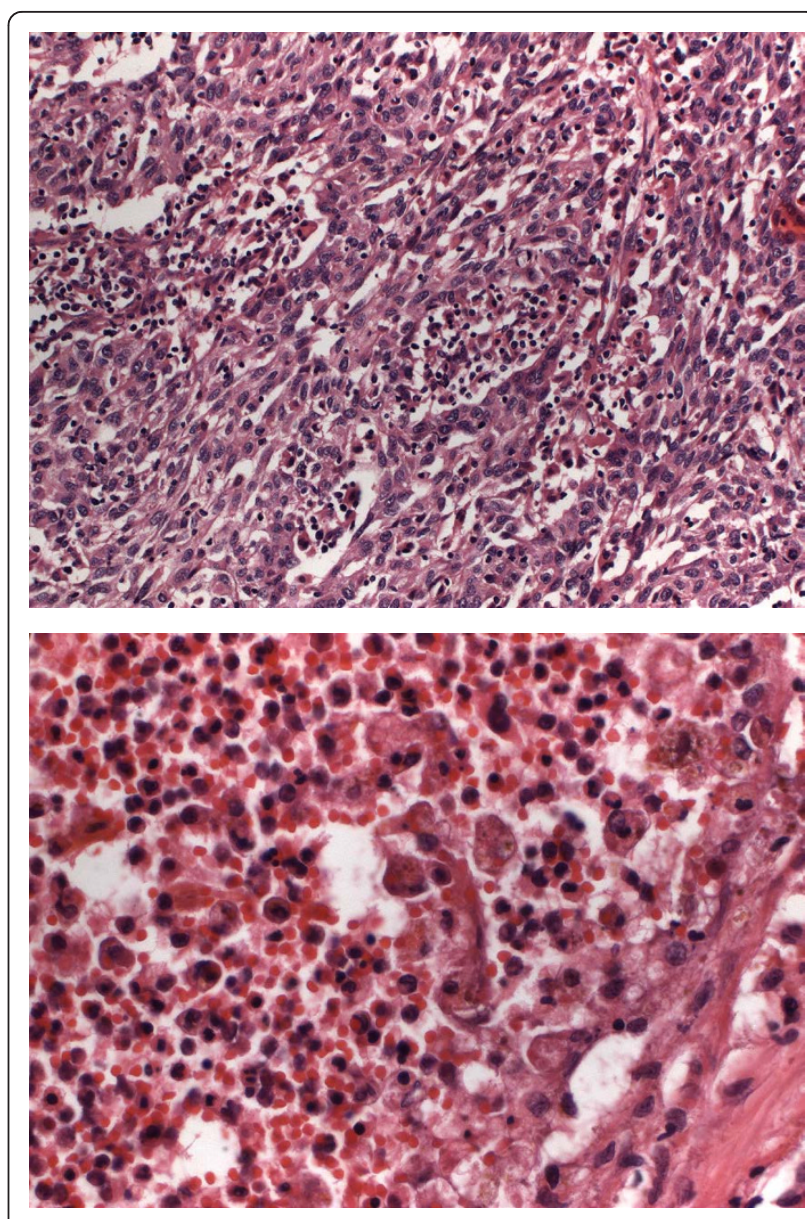

Figure $6 \mathrm{~A}$ and B: Resection specimen of the right kidney and adrenal gland reveals a poorly, in parts sarcomatoid differentiated renal carcinoma. Gross examination shows infiltration of the adenal gland, renal plevis and macroscopic vascular invasion. A: (H\&E, 200X) Spindle like shaped tumor cells with small eosiniphilic cytoplasmn and pleomophic nuclei with eosinophilic nucleoli. Interspersed small amounts of histiocytes and small lymphocytes. The amount of eosinophils is not elevated in viable tumor areas. B: (H\&E, 400X): Areas of tumor necrosis withs rims of histiocytes and increased number of eosinophils.

as the only promoter of increasing eosinophils in the present case and other sources for cytokines promoting hypereosinophilia are probable.

Paraneolastic eosinophilia is usually mild without any clinical symptoms, but absolute counts may occasionally exceed $25,000 / \mu \mathrm{l}$ and may cause end-organ damage. In a few reported cases of paraneoplastic hypereosinophilia, neurological symptoms occurred due to thromboembolic events with multiple infarctions [23,24,14]. Significantly reduced left ventricular function in our patient may be interpreted as end-organ damage as well.

Several studies have shown that paraneoplastic eosinophilia is a poor prognostic sign and indicates metastatic and extensive disease $[25,26]$. In a series of 36 cases 
with paraneoplastic hypereosinophilia, 32 patients had metastatic disease [27]. The patient reported here had a disseminated disease with pulmonary and bone metastases and presented with extraordinary rapid disease progression with poor response to surgical and systemic treatment. In previously reported cases, peripheral eosinophil count correlated with disease activity [28]. We could not find a clear correlation between tumor mass and absolute granulocyte count in the reported patient.

Symptomatic paraneoplastic eosinophilia could be treated with drugs leading to decreased production and function of eosinophilic granulocytes including glucocorticoids, hydroxyurea, vincristine $[29,30]$. Furthermore, reduction of tumor mass either by surgery or systemic treatment has been shown to reduce peripheral eosinophilic counts in paraneoplastic hypereosinophilia $[11,28]$.

In the present case, a combination of drugs directly targeting function and production of granulocytes (prednisone, hydroxyurea, vincristin, cytarabine) and drugs targeting renal carcinoma (sunitinib and temsirolimus) led to a decrease of absolute leukocytes and eosinophils. Neurologic impairment and general status significantly improved with reduced numbers of eosonophilic granulocytes. First line sunitinib had to be temporarily replaced by temsirolimus, as swallowing difficulties did not permit oral therapy. Temsirolimus led to a shortterm response (according to RECIST) 2 weeks after initiation. However, rapid progression was observed only 4 weeks after initiation of systemic therapy. As reduction of prednisone led to significant hypereosinophiliaassociated reduction of vigilance with prompt improvement after increase of dosage we consider prednisone as a mainstay of the therapeutic approach. Hence, it leads to reduced eosinophilic count and improvement of hypereosinophilia associated symptoms.

\section{Conclusions}

This is the first reported case in the literature of excessive paraneoplastic hypereosinophilia in a patient with metastatic renal cell carcinoma. Paraneoplastic hypereosinophilia due to renal cell carcinoma might indicate poor prognosis and rapid disease progression. Myelosuppressive therapy is required in symptomatic patients.

\section{Consent}

Written informed consent was obtained from the next of kin of the patient for publication of this Case report and any accompanying images. A copy of the written consent is available for review by the Editor-in-Chief of this journal.

\section{Acknowledgements}

None.

\section{Author details}

${ }^{1}$ Department of Urology, University Hospital Tuebingen, Tuebingen, Germany. ${ }^{2}$ Department of Internal Medicine, Oncology, Hematology, University Hospital Tuebingen, Tuebingen, Germany. ${ }^{3}$ Department of Pathology, University Hospital Tuebingen, Tuebingen, Germany. ${ }^{4}$ Department of Neuroradiology, University Hospital Tuebingen, Tuebingen, Germany. ${ }^{5}$ Department of Radiology, University Hospital Tuebingen, Tuebingen, Germany. ${ }^{6}$ Department of Urology, Eberhard-Karls University, Hoppe-Seyler Strasse 3, D-72076 Tübingen, Germany.

\section{Authors' contributions}

TT was responsible for concept, design, acquisition and interpretation of data. SW contributed to concept, design, acquisition and interpretation of data. CHW was responsible for microscopic and histopathologic elements. $\mathrm{SH}$ performed analysis and interpretation of cranial imaging. $\mathrm{MH}$ was responsible for radiologic elements and interpretation. $\mathrm{JH}$ was responsible for cytokine analysis and interpretation of data. AS contributed to concept and design of the study. LK contributed to concept and design of the study. CS was responsible for acquisition of data, interpretation and critical revision of the manuscript. All authors read and approved the final manuscript.

\section{Competing interests}

The authors declare that they have no competing interests.

Received: 7 November 2011 Accepted: 21 March 2012

Published: 21 March 2012

\section{References}

1. Bedke J, Buse S, Kurosch M, Haferkamp A, Jager D, Hohenfellner M: Paraneoplastic syndrome in renal cell carcinoma. Urologe A 2007, 46:45-48.

2. Da Silva JL, Lacombe C, Bruneval P, Casadevall N, Leporrier M, Camilleri JP, Bariety J, Tambourin P, Varet B: Tumor cells are the site of erythropoietin synthesis in human renal cancers associated with polycythemia. Blood 1990, 75:577-582

3. Moinzadeh A, Libertino JA: Prognostic significance of tumor thrombus level in patients with renal cell carcinoma and venous tumor thrombus extension. Is all T3b the same? J Urol 2004, 171:598-601.

4. Motzer RJ, Bacik J, Murphy BA, Russo P, Mazumdar M: Interferon-alfa as a comparative treatment for clinical trials of new therapies against advanced renal cell carcinoma. J Clin Oncol 2002, 20:289-296.

5. Beirne $P$, Pantelidis $P$, Charles $P$, Wells AU, Abraham DJ, Denton CP, Welsh Kl, Shah PL, du Bois RM, Kelleher P: Multiplex immune serum biomarker profiling in sarcoidosis and systemic sclerosis. Eur Respir J 2009, 34:1376-1382.

6. Yurkovetsky ZR, Kirkwood JM, Edington HD, Marrangoni AM, Velikokhatnaya L, Winans MT, Gorelik E, Lokshin AE: Multiplex analysis of serum cytokines in melanoma patients treated with interferon-alpha2b. Clin Cancer Res 2007, 13:2422-2428.

7. Cytokine concentrations in biological fluids. [http://www. copewithcytokines.de/cope.cgi?key=Cytokine\%20Concentrations\%20in\% 20Biological\%20Fluids]

8. Tefferi A, Patnaik MM, Pardanani A: Eosinophilia: secondary, clonal and idiopathic. Br J Haematol 2006, 133:468-492

9. Rothenberg ME: Eosinophilia. N Engl J Med 1998, 338:1592-1600.

10. Manelis G, Aderka D: Eosinophilia associated with malignant tumors of the bronchus and stomach. Harefuah 1976, 90:213-215.

11. Balian A, Bonte E, Naveau S, Foussat A, Bouchet-Delbos L, Berrebi D, Vons C Capron F, Chaput JC, Emilie D: Intratumoral production of interleukin-5 leading to paraneoplastic peripheral eosinophilia in hepatocellular carcinoma. J Hepatol 2001, 34:355-356.

12. Anagnostopoulos GK, Sakorafas GH, Kostopoulos P, Margantinis G, Tsiakos S, Terpos E, Pavlakis G, Fortun P, Arvanitidis D: Disseminated colon cancer with severe peripheral blood eosinophilia and elevated serum levels of interleukine-2, interleukine-3, interleukine-5, and GM-CSF. J Surg Oncol 2005, 89:273-275.

13. Ando J, Sugimoto K, Tamayose K, Ando M, Kojima Y, Oshimi K: Cytokineproducing sarcoma mimics eosinophilic leukaemia. Eur J Haematol 2007 78:169-170.

14. Rojas GJ, Castro DM, Vigo-Guevara GL, Ferrua M, Barriga-Maldonado V, Rotta-Escalante R: Hypereosinophilic encephalopathy with multiple 
cerebral infarctions in neighbouring vascular territories associated with prostate cancer. Rev Neurol 2006, 43:762-764.

15. Fridlender ZG, Simon HU, Shalit M: Metastatic carcinoma presenting with concomitant eosinophilia and thromboembolism. Am J Med Sci 2003, 326:98-101.

16. Watanabe M, Ono K, Ozeki Y, Tanaka S, Aida S, Okuno Y: Production of granulocyte-macrophage colony-stimulating factor in a patient with metastatic chest wall large cell carcinoma. Jpn J Clin Oncol 1998, 28:559-562.

17. Park S, Kim ES, Noh DY, Hwang KT, Moon A: H-Ras-specific upregulation of granulocyte colony-stimulating factor promotes human breast cell invasion via matrix metalloproteinase-2. Cytokine 2011, 55:126-133.

18. Karawajczyk M, Hoglund M, Ericsson J, Venge P: Administration of G-CSF to healthy subjects: the effects on eosinophil counts and mobilization of eosinophil granule proteins. Br J Haematol 1997, 96:259-265.

19. Simon HU, Plotz S, Simon D, Seitzer U, Braathen LR, Menz G, Straumann A Dummer R, Levi-Schaffer F: Interleukin-2 primes eosinophil degranulation in hypereosinophilia and Wells' syndrome. Eur J Immunol 2003, 33:834-839.

20. Costa JJ, Matossian K, Resnick MB, Beil WJ, Wong DT, Gordon JR, Dvorak AM, Weller PF, Galli SJ: Human eosinophils can express the cytokines tumor necrosis factor-alpha and macrophage inflammatory protein-1 alpha. J Clin Invest 1993, 91:2673-2684.

21. Goldstein LA, Strieter RM, Evanoff HL, Kunkel SL, Lukacs NW: TNF-induced IL-8 and MCP-1 production in the eosinophilic cell line, EOL-1. Mediators Inflamm 1996, 5:218-223.

22. Lo Re V III, Fox KR, Ferrari VA, Scott CH, Kossev PM, Kostman JR: Hypereosinophilia associated with cardiac rhabdomyosarcoma. Am J Hematol 2003, 74:64-67.

23. Takai K, Sanada M: Hypereosinophilic syndrome evolving to acute lymphoblastic leukemia. Int J Hematol 1991, 54:231-239.

24. Narayanan G, Hussain BM, Chandralekha B, Sivasankar C, Nair MK: Hypereosinophilic syndrome in acute lymphoblastic leukaemia-case report and literature review. Acta Oncol 2000, 39:241-243.

25. Lowe D, Jorizzo J, Hutt MS: Tumour-associated eosinophilia: a review. J Clin Pathol 1981, 34:1343-1348.

26. Chang WC, Liaw CC, Wang PN, Tsai YH, Hsueh S: Tumor-associated hypereosinophilia: report of four cases. Changgeng Yi Xue Za Zhi 1996, 19:66-70.

27. Isaacson NH, Rapoport P: Eosinophilia in malignant tumors; its significance. Ann Intern Med 1946, 25:893-902.

28. Balducci L, Chapman SW, Little DD, Hardy CL: Paraneoplastic eosinophilia. Report of a case with in vitro studies of hemopoiesis. Cancer 1989. 64:2250-2253.

29. Aldebert D, Lamkhioued B, Desaint C, Gounni AS, Goldman M, Capron A, Prin L, Capron M: Eosinophils express a functional receptor for interferon alpha: inhibitory role of interferon alpha on the release of mediators. Blood 1996, 87:2354-2360

30. Schleimer RP, Bochner BS: The effects of glucocorticoids on human eosinophils. J Allergy Clin Immunol 1994, 94:1202-1213.

\section{Pre-publication history}

The pre-publication history for this paper can be accessed here: http://www.biomedcentral.com/1471-2490/12/7/prepub

doi:10.1186/1471-2490-12-7

Cite this article as: Todenhöfer et al:: Severe paraneoplastic

hypereosinophilia in metastatic renal cell carcinoma. BMC Urology 2012 $12: 7$.

\section{Submit your next manuscript to BioMed Central and take full advantage of:}

- Convenient online submission

- Thorough peer review

- No space constraints or color figure charges

- Immediate publication on acceptance

- Inclusion in PubMed, CAS, Scopus and Google Scholar

- Research which is freely available for redistribution

Submit your manuscript at www.biomedcentral.com/submit
Biomed Central 